\title{
IQTISHODUNA
}

Vol. 17 (1), 2021

P-ISSN: 1829-524X, E-ISSN: 2614-3437

\section{Peran Nilai Islami Anggota Koperasi dalam Meningkatkan Eksistensi Lembaga}

\author{
Witri Retno Handayani', Umrotul Khasanah ${ }^{2}$ \\ 1,2, UIN Maulana Malik Ibrahim Malang, Indonesia
}

*Corresponding Author

E-mail: um_amana@pbs.uin-malang.ac.id

\begin{abstract}
The role of Islamic values in an institution properly and correctly will influence people's decisions to become members of the institution. This study aims to analyze the role and implications of Islamic values of the members of the KSU SWM Malang city, in improving the existence of the institution. The method used is descriptive qualitative research methods. Data collection techniques with in-depth interviews, observation and documentation. The informants in this study were several traders of the Dinoyo traditional market in Malang city, the chairman of the SWM cooperative management and the manager of the SWM cooperative. The results of the study found that the Islamic value of the members of the SWM cooperative was shown in the form of solidarity / teamwork, sincerity and trust in the good performance of the management, as well as the KSU-SWM manager.
\end{abstract}

Keywords: Islamic Values, Cooperatives, Cooperative Institutions

\begin{abstract}
Abstrak: Peran nilai Islami pada sebuah lembaga secara baik dan benar, akan mempengaruhi keputusan masyarakat untuk menjadi anggota pada lembaga tersebut. Penelitian ini bertujuan untuk menganalisis bagaimana peran dan implikasi nilai Islami anggota KSU SWM kota Malang, dalam meningkatkan eksistensi lembaganya. Metode yang digunakan adalah metode penelitian kualitatif deskriptif. Teknik pengumpulan data dengan wawancara mendalam, observasi dan dokumentasi. Informan dalam penelitian ini adalah beberapa pedagang pasar tradisional Dinoyo kota Malang, ketua pengurus koperasi SWM serta pengelola koperasi SWM. Hasil penelitian menemukan bahwa nilai Islami dari anggota koperasi SWM ditunjukkan dalam bentuk kebersamaan/teamwork yang solid, keikhlasan dan amanah dalam kinerjanya baik dari pengurus, juga pengelola KSU-SWM. Sikap para anggotanya yang
\end{abstract}


mayoritas pedagang pasar tradisional, yaitu sikap hemat dengan gemar menabung, serta sikap adil dari lembaga koperasinya, merupakan hubungan timbal balik yang saling menguntungkan. Dari nilai Islami tersebut, berperan dalam meningkatkan rasa kepercayaan/trust dari para anggotanya untuk tetap bergabung di KSU-SWM.

Kata kunci: Nilai Islami, Koperasi, Lembaga koperasi

| Draft awal November 2020 | Diterima Maret 2021 | Terbit April 2021 |

| DOI: http: //dx.doi.org/ 10.18860/iq.v17i1.9821

\section{Cara mencitasi:}

Handayani \& Khasanah. (2021). Peran Nilai Islami Anggota Koperasi dalam Meningkatkan Eksistensi Lembaga. Iqtishoduna, 17(1), 81-96.

\section{Pendahuluan}

Koperasi merupakan salah satu bentuk persekutuan yang melakukan kegiatan muamalah dalam bidang ekonomi. Koperasi boleh melakukan kegiatan apa saja dalam bidang ekonomi sepanjang bukan kegiatan yang dilarang oleh syariah. Lembaga keuangan memegang pernanan yang penting sebagai pengegrak roda dalam perekonomian negara, salah satunya adalah membantu pelaku usaha untuk menjalankan, memperluas serta mengembangkan kegiatan usahanya (Marlina \& Pratami, 2017). Di tengah kemajuan perkembangan ekonomi syariah di Indonesia, Lembaga keuangan mikro seperti koperasi syariah tidak luput dalam bantuan memberikan pembiayaan melalui pinjaman kepada para anggotanya.

Kehadiran koperasi syariah diharapkan mampu unetuk melakukan pemberdayaan kalangan masyarakat menengah ke bawah yang diwujudkan melalui pemberian pembiayaan usaha kecil, mikro dan menengah yang dijalankan sesuai dengan prinsip-prinsip syariah (Abdurahman \& Yahya, 2015). Dalam sebuah lembaga keuangan, terutama yang ber-visi maupun misi sesuai syariat Islam, dalam menerapkan nilai-nilai dalam sistem baik manajemen operasionalnya maupun sumber daya insaninya, dimana nilainilai Islami yang berasal dari prinsip-prinsip syariah tidak hanya menjadi symbol saja, tetapi harus teraplikasi secara nyata dalam setiap aktivitas lembaga keuangan. Dari mulai karyawan terendah sampai pada manajerial puncak, bahkan sampai pada nasabah atau anggota lembaga keuangan itu sendiri. Hal tersebut agar lembaga dapat senantiasa berada dalam koridor

82| IQTISHODUNA Vol. 17 (1), 2021 http://ejournal.uin-malang.ac.id/index.php/ekonomi 
nilai-nilai Islam, guna mencapai pengembangan ke arah yang lebih baik lagi.

Peran nilai-nilai Islami pada sebuah lembaga koperasi yang berbasis syariah secara baik dan benar, tentu saja akan mempengaruhi keputusan masyarakat untuk menjadi anggota koperasi tersebut. Kepercayaan anggota untuk memanfaatkan fasilitas yang ada pada koperasi tersebut, baik dengan menyimpan dana maupun mengajukan pembiayaan, akan semakin meningkat (Jatun \& Magnadi, 2015). Dengan kata lain, mereka akan menjadi anggota atau nasabah yang loyal pada lembaga koperasi tersebut. Nilai-nilai yang ada dalam organisasi menjadi daya tarik sehingga orang diluar organisasi tersebut tertarik untuk masuk ke dalamnya. Secara umum nilainilai inilah yang menjadi akar dari budaya organisasi, utamanya bila nilainilai yang dimaksudkan di dukung oleh anggota organisasi. Adapun bentuk dari nilai-nilai yang dimaksud diantaranya tampak dari pengorbanan anggota dalam melakukan pekejaan organisasi. Dari sisi organisasi, nilai-nilai tersebut akan tampak pada tujuan dan strategi organisasi (Husni, 2014).

Koperasi merupakan sarana yang tepat untuk meningkatkan kesejahteraan khususnya bagi golongan ekonomi lemah, baik untuk usaha mikro, kecil maupun menengah. Koperasi dapat dimanfaatkan sebagai alat perjuangan ekonomi dalam menghadapi persaingan dengan usaha besar kapitalis (Sukidjo, 2008). Dewasa ini citra koperasi di mata masyarakat kurang baik, sehingga masyarakat cenderung memberi kesan negative terhadap koperasi. Hal tersebut disebabkan banyak koperasi yang gagal, banyak koperasi yang disalahgunakan oleh Pengurus, dan banyak koperasi yang tidak professional. Koperasi sebagai lembaga keuangan mikro, kerap mengalami sejumlah kendala internal dan eksternal, baik dari aspek manajemen operasionalnya juga SDM yang masih terbatas (Subadriyah \& Rohman, 2015). Meski begitu, banyak diantara mereka berhasil bertahan, dimana pengelolaannya juga tidak mudah, sebab diawal berdirinya dikelola dengan manajemen secara mandiri, dan yang sering jadi persoalan, sumber daya insaninya.

Salah satu koperasi yang berbadan hukum koperasi serba usaha yang berlokasi di Dinoyo kota Malang, yaitu Koperasi Serba Usaha-Sarana Wiraswasta Muslim yang biasa disingkat dengan KSU-SWM, dimana KSU ini sudah cukup lama bisa bertahan dalam menggerakkan usaha lembaganya, dengan kondisi perkembangan asset maupun jumlah anggotanya yang seiring bertambah tiap tahun, meski juga pernah mengalami naik turun, bisa bertahan hingga sekarang. KSU-SWM berdiri sejak September tahun 1996

IQTISHODUNA Vol. 17 (1), 2021 |83 
oleh beberapa aktivis gerakan koperasi, LSM dan tokoh masyarakat yang peduli dengan pemberdayaan ekonomi rakyat yang berdasarkan syariat Islam.

Pelayanan pinjaman maupun simpanan dari KSU-SWM ini secara tidak langsung ingin memberantas atau menjaga anggotanya agar terhindar dari tawaran bank atau lembaga lain yang menggunakan sistem bunga di pasar tradisional. Meski di area pasar dan sekitarnya, juga ada beberapa lembaga keuangan mikro lain yang cukup gencar dan lama beroperasi dalam menarik minat para pedagang pasar untuk bergabung, namun para anggota KSU-SWM ini masih bisa tetap loyal untuk menjadi anggota KSU-SWM. Dengan sistem kepercayaan pada anggota baru yang diawali dengan sistem menabung selama minimal 3 bulan di awal, akan mendapat fasilitas pembiayaan dari koperasi sesuai prosedur atau kriteria yang telah ditetapkan oleh koperasi SWM (bisa pula pinjaman tanpa jaminan tergantung juga dari hasil analisa pada anggota).

Dalam kurun waktu berdirinya koperasi serba usaha ini selama kurang lebih hingga sekarang telah 23 tahun, dari segi permodalan mulai awal didukung penuh oleh anggotanya, meski demikian dalam perjalanannya pernah pula mendapat pinjaman modal dari Bank yang bermitra dengan koperasi. Dengan mengedepankan etika moral sesuai sistem nilai-nilai organisasi yang diterapkan di KSU ini, diharapkan dapat menunjang serta meningkatkan eksistensi organisasi atau menjaga trust /kepercayaan bagi masyarakat terutama yang sudah menjadi anggota koperasinya. Dengan mengedepankan kaidah etika moral dalam operasionalnya, akan berimbas trust (kepercayaan) di masyarakat maupun anggota koperasinya bisa terjaga dan konsisten. Peneliti tertarik untuk meneliti dan mengkaji lebih mendalam Koperasi SWM sebagai koperasi serba usaha dalam upayanya mengaplikasikan sistem atau nilai-nilai yang Islami anggotanya baik dari segenap pengurus maupun karyawan dan semua anggota dalam rangka menjaga keberadaan atau eksisnya sebuah lembaga koperasi.

\section{Kajian Pustaka}

\section{Nilai-nilai Islam dalam Budaya Organisasi}

Kegiatan ekonomi dalam ajaran Islam merupakan bagian dari muamalah (Mursal \& Suhadi, 2015). Secara umum, prinsip nilai Islam dalam kehidupan aktivitas ekonomi masyarakat, harus mengedepankan nilai-nilai

84| IQTISHODUNA Vol. 17 (1), 2021

http://ejournal.uin-malang.ac.id/index.php/ekonomi 
yang Islami yaitu :

a. Mencari ridho Allah. Hal tersebut teramat penting karena segala tindakan manusia tidak hanya mementingkan duniawi saja tetapi juga harus mementingkan tujuan di akhirat nanti, yang akhirnya untuk mencapai ridho Allah SWT. Dengan niat beribadah kepada Allah SWT, apapun profesi maupun pekerjaan kita, sehingga menambah iman dan takwa kita kepada-Nya. Dengan niat segala kegiatan yang dilakukan hanyalah untuk mencari ridho Allah SWT, sesuai dengan firman Allah dalam surat Al-Mulk ayat 15.

b. Iman yang kuat. Intinya dengan adanya iman kepada Allah SWT, merupakan pengawas yang utama dalam segala kegiatan atau aktivitas yang dilakukan, sehingga apa yang dilakukan adalah hal-hal yang baik dan menjauhkan dari hal-hal yang haram.

c. Perwakilan harta Allah SWT. Sistem nilai kepemilikan dalam Islam yaitu bahwa sesungguhnya semua kepemilikan manusia sejatinya kepemilikan tersebut merupakan "wakil" dari yang Maha Memiliki yaitu Allah SWT. Dia-lah yang menciptakan dan memilikinya, sedang manusia adalah wakil dan pemegang amanah terhadap harta tersebut.

d. Akhlaqul Karimah. Dalam kehidupan Islam, akhlaq memegang peranan utama. Dengan diutusnya Rasulullah SAW untuk menyempurnakan akhlaq, sesuai hadits Rasulullah:" Sesungguhnya tiadalah aku diutus, melainkan hanya untuk menyempurnakan akhlaq." (HR. Muslim). Dalam kehidupan ekonomi, Islam berpandangan bahwa dalam melakukan aktivitas bisnis harus menjunjung tinggi etika bisnis dan ajaran moral Islam. Sumber inspirasi sistem nilai ekonomi Islam mengambil kekuatan dari wahyu al-Qur'an, yaitu sistem ekonomi yang berakhlaq. Dimana akhlaq ini mampu memberikan makna baru terhadap konsep nilai, dan mampu mengisi kekosongan pikiran yang nyaris muncul akibat alat industrialisasi (Qardhawi, 2001).

e. Tidak dzalim dan harus adil. Seorang muslim yang baik tidak akan melakukan yang dilarang dalam agama seperti perbuatan dzalim, karena dengan berbuat dzalim tersebut, maka berkeyakinan bahwa Allah akan membalasnya. Jadi dalam ekonomi Islam harus dihindari perbuatan tersebut.

f. Tidak ada unsur riba. Larangan Allah SWT terhadap pengambilan riba sudah jelas dan pasti, yang terdapat dalam surat al-Baqarah ayat

IQTISHODUNA Vol. 17 (1), 2021 |85 http://ejournal.uin-malang.ac.id/index.php/ekonomi 
275. Sistem ekonomi Islam menghendaki pemisahan secara tegas antara pemasukan atau pengeluaran yang berbau riba dan yang bukan.

g. Tidak ada unsur penipuan dan bersikap jujur.

h. Keseimbangan. Prinsip keseimbangan ini adalah tidak menyianyiakan dan tidak berlebih-lebihan, tidak melampaui batas dan tidak pula merugikan, sesuai firman Allah SWT dalam surat ar-Rahman ayat 7-9.

i. Menghindari fitnah. Harta dalam ekonomi Islam, akan menguji kepada pemiliknya, apakah bersyukur ataukah kufur. Allah menyebut harta dengan "fitnah" yaitu ujian dan cobaan yang terdapat dalam al-Qur'an surat al-Anfaal ayat 28.

j. Kemaslahatan. Sesuai hadits Rasulullah SAW, bahwa: "Tidak boleh ada bahaya dan tidak boleh pula membahayakan (orang lain)" (HR. Ahmad dan Ibnu Majah dari Ibnu Abbas dan Ibnu Majah dari Ubadah bin Shamit, sebagaimana terdapat dalam Shahih-al-Jami' ash-Shagir: 7517). Islam mengharamkan kepada pemilik harta menggunakan kepemilikannya untuk berbuat kerusakan di muka bumi atau melakukan sesuatu yang membahayakan manusia.

k. Meyakini adanya konsep barokah. Konsep tentang barokah ini meliputi semua spektrum perilaku manusia. Ada tidaknya sebuah barokah amat tergantung pada benar tidaknya sebuah perilaku dan tindakan seseorang. Sesuai firman Allah SWT: " Allah memusnahkan riba dan menyuburkan sedekah. Allah tidak menyukai setiap orang yang tetap dalam kekafiran dan bergelimang dosa (QS. Al-Baqarah ayat 276).

Hafidhuddin (2003), berpendapat bahwa bagi seorang manajer muslim, nilai yang dipandang paling benar adalah nilai yang bersumber dari ajaran agamanya, yaitu Islam. Bagaimanapun, sebuah organisasi akan sehat bila dikembangkan dengan nilai-nilai sehat yang bersumber dari agama. Beberapa nilai yang dipandang penting dalam pembangunan mental seorang muslim dalam berorganisasi adalah ikhlas, jamaah dan amanah.

Hafidhuddin dan Tanjung (2003), menyatakan bahwa budaya perusahaan syariah juga harus mencerminkan nilai-nilai Islam, yaitu : Cara melayani nasabah, Cara berpakaian, Membiasakan sholat berjamaah, Berdoa sebelum dan sesudah selesai bekerja, dan sebagainya. Hakim (2011), mengungkapkan karakteristik budaya organisasi yang Islami terdiri dari : Smiling: To create the atmosphere of attention, Greetings: To create welfare

86| IQTISHODUNA Vol. 17 (1), 2021

http://ejournal.uin-malang.ac.id/index.php/ekonomi 
atmosphere, Friendship: Good relationship among the employees both managers and staffs, Helping among the others, having good cooperation, Never telling a lie, Discipline: "Using the time as well as possible. Karakteristik tersebut merupakan sistem nilai yang di ambil dan dikembangkan dari AlQur'an dan Hadits yang dipraktekkan dalam kehidupan sehari-hari.

\section{Menjaga dan Mengembangkan Eksistensi Koperasi}

Menurut Krisnamurti (2007); ada beberapa faktor fundamental yang mempengaruhi eksistensi koperasi, yaitu : Jika terdapat kebutuhan kolektif untuk memperbaiki ekonomi secara mandiri, Jika terdapat kebebasan dan otonomi untuk berorganisasi, Keberadaan koperasi akan ditentukan oleh proses pemahaman nilai-nilai koperasi, Adanya kesadaran dan kejelasan tentang keanggotaan, Apabila mampu mengembangkan kegiatan usaha yang luwes sesuai kepentingan anggota, berorientasi pada pelayanan anggota, berkembang sejalan dengan perkembangan usaha anggota, hemat serta mampu mengembangkan modal koperasi maupun modal anggota.

Faktor-faktor lain yang memperkuat nilai-nilai dalam suatu lembaga atau perusahaan adalah Nilai, norma dan pola perilaku diterima oleh masyarakat yang makin luas, Adanya kepemimpinan yang berkesinambungan, Keanggotaan yang makin mapan dan makin loyal, Konsentrasi geografis (Rivai \& Darsono , 2015).

Secara ideal perusahaan atau lembaga yang memiliki nilai-nilai atau budaya yang kuat, dapat menciptakan kinerja yang bagus ditandai bahwa perusahaan itu memiliki : a. Tujuan yang jelas, b. Karyawan memiliki motivasi tinggi, loyal,kerja keras, karena mereka senang bekerja di perusahaan tersebut, c. Struktur dan kontrol yang luwes, d. Karyawan yang memiliki kesadaran yang tinggi tentang kelangsungan hidup perusahaan(Rivai \& Darsono , 2015).

Berdasar hasil kajian terhadap berbagai koperasi di Indonesia yang sukses, Mulyo (2007), mengidentifikasi beberapa faktor kunci sukses dalam rangka pengembangan dan pemberdayaan koperasi, yakni : a. Pemahaman pengurus dan anggota terhadap jati diri koperasi, meliputi pengertian koperasi, nilai-nilai koperasi dan prinsip gerakan koperasi, b. Kemampuan pengurus untuk mengidentifikasi kebutuhan kolektif anggota, c. Adanya kesungguhan pengurus dan pengelola dalam mengelola koperasi, d. Kegiatan usaha koperasi harus bersinergi dengan usaha anggota, e. Biaya transaksi antara koperasi dengan anggota lebih rendah jika dibanding dengan biaya transaksi antara anggota terhadap badan usaha non koperasi.

IQTISHODUNA Vol. 17 (1), $2021 \mid 87$

http://ejournal.uin-malang.ac.id/index.php/ekonomi 


\section{Pengembangan Profesionalitas SDM di lembaga keuangan syariah}

Prinsip syariah bagi praktisi di Lembaga Keuangan Syariah harus sesuai dengan prinsip-prinsip Islam, termasuk di dalamnya adalah tradisi dan kultur Islam. Wujud nilai agamis tersebut diwujudkan dalam aktivitas keseharian yang berupa: a. Sebelum memulai membuka pelayanan, maka para karyawan terlebih dahulu membaca Al-Qur'an dan berdoa bersama, b. Tidak mengeluarkan kata-kata"kotor" jika mendapatkapermasalahan dari nasabah, seperti misal nasabah yang tidak tepat janji dalam mengangsur, c. Selalu mengawali aktivitas dengan basmalah, dan mengakhirinya dengan hamdalah, d. Memberikan pelayanan dengan ramah, sopan dan selalu mengucapkan salam kepada nasabah.

\section{Metodologi Penelitian}

Metode penelitian yang digunakan dalam tulisan ini adalah kualitatif deskriptif pendekatan fenomenologi Islam. Fokus utama fenomenologi agama adalah aspek pengalaman keagamaan, dengan mendeskripsikan atau menggambarkan fenomena keagamaan secara konsisten dalam orientasi keimanan atau kepercayaan obyek yang diteliti. Data yang dihimpun oleh peneliti adalah data primer (utama) dan data sekunder (penunjang). Data primer diperoleh langsung dari sumbernya melalui wawancara dengan pihak terkait di Koperasi Serba Usaha Sarana Wiraswasta Muslim/KSU SWM, beberapa key informan (ketua pengurus dan pengelola KSU SWM juga beberapa anggotanya dari pedagang yang sudah senior), informan pendukung (beberapa anggota dari pedagang di pasar dinoyo yang dianggap mewakili). Data sekunder diperoleh dari studi kepustakaan baik berupa jurnal, buku, internet, guna mencari landasan pemikiran dan pemecahan masalah, khususnya di lembaga keuangan mikro yaitu Lembaga koperasi.

Teknik pengumpulan data dengan observasi, wawancara (interview) dan dokumentasi. Analisa data, peneliti menggunakan Teknik analisa data model Miles dan Huberman (1992), dengan tiga tahapan yaitu reduksi data, penyajian data dan penarikan kesimpulan. Teknik ini dipilih karena sesuai dengan tujuan pengambilan data hingga mendapatkan data jenuh. Peneliti pada saat wawancara sudah melaksanakan analisa data, sehingga apabila didapatkan jawaban yang kurang memuaskan akan diajukan pertanyaan sampai mendapatkan jawaban yang kredibel. Untuk memeriksa keabsahan data peneliti menggunakan Teknik triangulasi. Peneliti menggunakan observasi partisipatif, wawancara mendalam, serta dokumentasi untuk

88| IQTISHODUNA Vol. 17 (1), 2021

http://ejournal.uin-malang.ac.id/index.php/ekonomi 
sumber data yang sama secara serempak. Pengambilan data harus disesuaikan dengan kondisi narasumber. Teknik yang digunakan dalam penelitian ini adalah triangulasi sumber yaitu dengan cara membandingkan dan mengecek informasi yang diperoleh. Penelitian melakukan pengecekan ulang sumber dengan membandingkan hasil wawancara dengan isi suatu dokumen yang berkaitan. Menguji kredibilitas data dengan mengecek data yang telah diperoleh melalui beberapa sumber.

\section{Hasil Dan Pembahasan}

\section{Gambaran Umum Koperasi Serba Usaha Sarana Wiraswasta Muslim (KSU SWM)}

Koperasi Serba Usaha Sarana Wiraswasta Muslim (KSU SWM) yang berdomisili di kota Malang, dirintis pendiriannya sejak bulan September pada tahun 1996 oleh beberapa aktivis gerakan koperasi, LSM dan tokoh masyarakat yang peduli dengan pemberdayaan ekonomi rakyat yang berdasarkan syariat Islam. KSU-SWM didirikan dalam rangka menggalang kekuatan kolektif masyarakat dari berbagai kalangan pedagang dan wirausahawan lainnya, dengan mengembangkan lembaga keuangan syariah. Dan baru disahkan oleh pemerintah sesuai dengan badan hukum tahun 1998 sebagai KSU Sarana Wiraswasta Muslim. Beberapa unit usaha yang dikelola oleh KSU SWM yaitu, Unit Jasa Keuangan Syariah, Unit travel umroh dan unit Baitul Maal

\section{Implementasi Nilai Islami SDM pada Koperasi Serba Usaha Sarana Wiraswasta Muslim}

KSU-SWM sebagai lembaga yang memfasilitasi para pedagang pasar tradisional (sebagai pelaku UKM) untuk pelayanan baik simpan pinjam juga unit usaha lain. KSU-SMW mengedepankan sistem bebas bunga/tanpa riba (pola syariah). Pedoman standar operasional manajemen Koperasi berbasis syariah, antara lain yaitu berasaskan kekeluargaan dan berlandaskan syariah Islam yaitu Al-Qur'an dan As-Sunnah dengan saling tolong menolong (ta'awun) dan saling menguatkan (takaful). Sumber daya manusia sebagai salah satu faktor pendukung yang mempengaruhi kemampuan koperasi di dalam menjalankan usaha. Sumber daya manusia yang berkualitas sangat dibutuhkan karena sumber daya manusia merupakan salah satu hal yang akan mendukung kemampuan usaha koperasi (Setyorini \& Kusumantoro, 2016). Beberapa nilai Islami yang diterapkan oleh anggota koperasi KSU-

IQTISHODUNA Vol. 17 (1), 2021 |89

http://ejournal.uin-malang.ac.id/index.php/ekonomi 
SMW dikemukakan oleh salah satu pengurus koperasi:

"kita sebagai pengurus koperasi, itu harus amanah dalam bekerja...harus memenuhi semua peraturan yang ada disini...agar berkah untuk kita nantinya"

Dari penuturan responden diatas dapat kita lihat bahwa salah satu nilai Islam yang diterapkan oleh pengurus koperasi adalah prinsip amanah. Islam menganggap berbagai jenis sumber daya yang ada adalah pemberian Allah kepada manusia. Manusia harus dapat memanfaatkannya dengan maksimal untuk memenuhi kesejahteraan secara bersama untuk diri sendiri dan untuk orang lain. Kegiatan yang dilakukan akan dipertanggungjawabkan di akhirat nantinya. Amanah merupakan sesuatu yang dipercayakan kepada orang lain untuk digunakan sebagaimana mestinya sesuai dengan keinginan yang mengamanahkan (Triiyuwono, 2002). Pihak yang mendapatkan amanaj tidak memiliki kewajiban pemilikan mutlak atas apa yang diamanahkan dan memiliki kewajiban untuk selalu memelihara amanah tersebut dengan baik (Kholmi, 2002).

Selain itu, responden pengurus koperasi menuturkan :

"Koperasi itu usaha bersama, kita bersama dengan anggota koperasi untuk jalan bareng bareng semuanya...kita memberikan dana pinjaman kepada mereka dan anggota yang meminjam juga berusaha bagaimana membayar kembali ke koperasi..."

Penuturan responden diatas menunjukkan bahwa salah satu nilai islami yang diterapkan oleh pengurus koperasi adalah prinsip kerjasama dalam kebaikan. Kekuatan utama ekonomi islam adalah kerjasama. Seorang mulsim, apakah ia sebagai pembeli, penjual, pembuat keuntungan dan sebagainya ahrus berpengang pada tuntunan Allah. Upaya pencapaian tujuan, harus selalu didasari dengan nilai-nilai Islam (Mustaqim, 2016). Responden lain menuturkan:

“ transkasi yang dilakukan disini tanpa bunga tanpa riba,karena kita tahu kan riba itu dosa besar..."

Hal tersebut mencerminkan salah satu nilai Islam yang diterapkan oleh sumber daya manusia dalam koperasi adalah prinsip keadilan. Islam melarang setiap pembayaran bunga atau riba atas berbagai bentuk pinjaman. Riba akan menyakiti salah satu pihak, sehingga akan menimbulkan ketidakadilan. Islam mengajarkan jual beli yang adil serta melarang riba. Islam melarang orang melakukan riba, karena riba pada dasarnya akan

90 | IQTISHODUNA Vol. 17 (1), 2021

http://ejournal.uin-malang.ac.id/index.php/ekonomi 
melahirkan sebuah ketidakadilan (Latifah). Dalam konsep Islam menggunakan bagi hasil (nisbah), sebagaimana pada produk mudharabah. Koperasi akan memberikan dana pinjaman untuk kepentingan pengusaha atau anggota dalam emnjalankan suatu badan usaha atau anggota koperasi, terhadap modal yang dipinjamkan koperasi tidak memberikan bunga, tetapi bagi hasil yang jumlahnya tergantung pada besar kecilnya laba yang akan diperoleh kemudian (Kholmi, 2002).

Sumber daya manusia merupakan aset dalam organisasi, yang menyumbangkan tenaga serta kemampuannya untuk organisasi. Sumber daya manusia sengat penting keberadaanya, secanggih apapun teknologinya tetap saja membutuhkan manusia sebagai pengelolanya. Sehingga sumber daya yang unggul yang dimiliki oleh perusahaan adalah hal utama yang harus diperhatikan oleh perusahaan.

\section{Kualitas pelayanan Islami anggota koperasi SWM}

Saat ini persaingan dalam layanan keuangan sudah sangat berkembang. Dalam rangka meningkatkan pangsa pasar Lembaga keuangan mikro ssperti koperasi syraiah perlu dilakukan, dimana mereka dituntut untuk memiliki daya saing dengan memiliki stratgei pemasaran yang efektif, salah satunay dengan memberikan pelananan terbaik kepada anggota dan nasabahnya. Upaya yang dilakukan dalam meningkatkan kuelitas layanan koperasi harus berorientasi kepada pasar atau masyarakat sebagai pengguna jasa koperasi. Hal ini berhubungan dengan harapan masyarakat, dimana mereka ingin mendapat hubungan yang baik dengan koperasi secara nyaman dan mudah. Salah satu pengurus koperasi menutrukan:

"kalau disini buka sesuai jam layanan operasional ya jam 9 buka, selain itu kita memberikan pelaynan dengan konsep $3 S$ yaitu senyum, sapa, salam...”

Dari uraian tersebut dapat kita lihat bahwa dalam menjaga kualitas layanannya adalah dengan menjaga tanggung jawab berupa kedisipilinan waktu. Hal ini memastikan bahwa anggota koperasi dapat melakukan transaksi tepat waktu sesuai dengan jalm layanan operasional koperasi. Selain kedisiplinan waktu, melayani dengan rendah hati (Khidmah) juga dilakukan dengan memebrikan pelayanan secara ramah tamah, sopan satun, murah senyum, namun tetap. bertanggung jawab (Rafidah, 2014). Keramahan merupakan salah satu kunci keberhasilan dalam pelayanan.

Responden lainnya menuturkan:

"disini pelayannya ada jemput bola langsung bertemu dengan para

IQTISHODUNA Vol. 17 (1), $2021 \mid 91$ 
anggotanya di lapangan, menjadi layanan yang praktis serta adil".

Salah satu pelyanan yang diberikan adalah pelayanan jemput bola.Strategi jemput bola dilakukan sebagai salah satu strategi untuk mendekatkan diri kepada anggota koperasi dengan mempermudah anggota untuk dapat mengakses layanan koperasi (Triandhini, 2013). Layanan jemput bola dilakukan dengan mendatangi secara langsung anggota dan calon anggota koperasi sehingga mereka tidak perlu repot repot untuk datang ke koperasi. Sebagain besar anggota koperasi adalah epdangan. Mereka yang berprofesi sebagai pedangang setiap ahrinya pasti akan memiliki penghasilan, walapun penghasilkan yang mereka dapakan setiap harinya tidak tetap. Disisi lain, kebutuhan yang mereka keluarkan untuk operasional berdagang tidak menentu. Hal ini kemudian menjadi celah untuk melakukan strategi jemput bola untuk memberikan pelayanan terbaik kepada anggota. Mereka dapat menabung atau membayar cicilan setiap harinya sewaktu waktu tanpa ahrus datang ke kantor, sehingga hal ini tidak akan menganggu waktiivtas mereka. Selain itu prinsip adil juga dijunjung tinggi dalam memberikan pelayanan kepada anggotanya. Semua anggota koperasi harus dilayani serta diperlakukan yang sama.

Selain itu ada responden lain yang mengemukakan:

"Koperasi kan dari anggota dan untuk anggota, jadi ya kita harus tolong menolong pada anggota yang memang butuh dana dari kami..."

Didasari sikap ta'awun/tolong menolong pada pelaku UKM terutama yang benar-benar membutuhkan modal usaha, adanya fasilitas pinjaman tanpa jaminan, berlaku untuk semua anggota sesuai kriteria atau aturan yang ada di koperasi SWM. Dalam koperasi, prinsip tolong menolong akan dikedepankan. Prinsip keterpaksaan tidak akan dijumpai dalam perkumpulan koperasi yang memiliki tujuan ekonomi yang jelas. Gotong royong serta tolong menolong dalam koperasi bertujuan sosial. Selain itu, Munkner (2012) mengenukakan bahwa koperasi merupakan sebuha organisasi yang berasarkan apda tolong menolong yang mengelola urusniaga secara berkelompok untuk membantu meperbaiki taraf hidup maupun ekonomi anggotanya.

Dengan adanya sikap yang Islami dari petugas atau SDM koperasi SWM, secara tidak langsung akan berimbas pada sikap percaya/trust terhadap koperasi SWM tersebut. Peran nilai Islami baik dari pengurus, pengelola juga anggota, dimana dalam sebuah koperasi baik personal yang ada dalam struktur organisasi maupun diluar struktur organisasi berarti

92| IQTISHODUNA Vol. 17 (1), 2021

http://ejournal.uin-malang.ac.id/index.php/ekonomi 
semua termasuk anggota koperasi, dapat berperan dalam menjaga rasa kepercayaan/trust terhadap Lembaga koperasinya.

\section{Implikasi dari Peran Nilai Islami Anggota Koperasi SWM dalam Meningkatkan Eksistensi Lembaga}

Implikasi dari adanya peran nilai Islami para anggota di koperasi SWM kota Malang, nampak berimbas dengan adanya transparansi dari Lembaga koperasinya, yang bisa diartikan dengan adanya keterbukaan, tekait dengan koperasi bisa diartikan dengan kejelasan tentang keanggotaan, serta dalam hal laporan organisasi, juga adanya proses pemahaman nilai-nilai koperasi, sehingga menunjang eksisnya atau keberadaan koperasi. Pengertian tersebut menurut peneliti sesuai seperti dituturkan oleh perwakilan dari anggota yang menjadi informan dalam penelitian ini, bahwa masalah laporan yang di laporkan waktu RAT pun juga terbuka, yang penting sebagai anggota juga jelas bentuk tanggungjawab koperasinya pada anggota agar kepercayaan pada koperasi bisa terjaga.

Selain itu implikasi dari peran nilai Islami anggota koperasi SWM nampak juga seperti kedisplinan (baik pengurus juga anggotanya), loyalitas (pengurus dan anggotanya) serta pelayanan prima SDM koperasinya. Seperti disiplin waktu dalam lingkungan kerja (datang tepat waktu, konsisten dalam bekerja terutama hal pelayanan yang prima ke anggota) juga loyalitas karyawan dalam pekerjaannya, bisa dikatakan dalam KSU SWM ini sudah cukup berjalan dengan baik dan cukup optimal. Lama masa kerja dari masing-masing para karyawannya di koperasi SWM meski dengan hasil yang diperoleh tiap bulan dengan bekerja di koperasi ini (yang tidak hanya mengejar profit bisnis semata) terasa kadang masih kurang atau belum mencukupi, namun dengan niat ikhlas ibadah dalam bekerja bisa memacu semangat dalam pekerjaan dan imbasnya juga bisa melayani dengan prima pada anggotanya, sehingga peran dari sikap pengurus (yang otomatis juga sebagai anggota pula) dari KSU SWM ini dapat berimbas pada eksisnya lembaga hingga sekarang dan masa mendatang.

\section{Kesimpulan}

Untuk meningkatkan kesejahteraan masyarakat dan mewujudkan keadilan sosial yang sesuai dengan konsep Islam, koperasi syariah hadir di masyarakat. Nilai nilai yang ada pada syariat Islam menjadi dasar dan bagian

IQTISHODUNA Vol. 17 (1), $2021 \mid 93$

http://ejournal.uin-malang.ac.id/index.php/ekonomi 
dari kehidupan sebagian besar pendudukan Indonesia. Salah satu aspek yang mendukung dalam keberhasilan koperasi syariah adalah sumber daya manusia. Hasil penelitian menunjukkan ada beberapa implementasi nilai islami pada koperasi serba usaha sarana wiraswasta muslim, antara lain amanah, prinsip kerjasama dalam kebaikan, serta prinsip menghindari riba. Selain itu, menjaga kualitas layanan perlu dilakukan koperasi sebagai cara untuk mengahdai persaingan dengan lembaga keuangan lainnya. Hasil penelitian menunjukkan kualitas layanannya adalah dengan menjaga tanggung jawab berupa kedisiplinan waktu. Salah satu pelayanan yang diberikan adalah pelayanan jemput bola. Strategi jemput bola dilakukan sebagai salah satu strategi untuk mendekatkan diri kepada anggota koperasi dengan mempermudah anggota untuk dapat mengakses layanan koperasi.

Sifat menolong juga dilakukan sebagai salah satu langkah yang dilakukan dalam mengedepankan kualitas layanan koperasi. Dengan mengedepankan etika moral sesuai sistem nilai-nilai organisasi yang diterapkan di KSU ini, diharapkan dapat menunjang serta meningkatkan eksistensi organisasi atau menjaga trust/kepercayaan bagi masyarakat terutama yang sudah menjadi anggota koperasinya. Dengan mengedepankan kaidah etika moral dalam operasionalnya, akan berimbas kepercayaan di masyarakat maupun anggota koperasinya bisa terjaga dan konsisten.

\section{Daftar Pustaka}

Abdurahman, H., \& Yahya, A. (2015). Bisnis Dan Muamalah Kontemporer. Bogor: Al-Azhar Fresh Zone.

Hafidhuddin, D. (2003). Manajemen Syariah dalam praktik. Jakarta: Gema Insani Press.

dan Tanjung, (2003). Manajemen Syariah dalam Praktik. Jakarta: Gema Insani Press.

Hakim, L. (2011). Artikel Budaya organisasi Islami sebagai upaya meningkatkan kinerja.

Husni, M. (2014). Membangun Budaya organisasi dalam perspektif nilai-nilai Islam. Malang.

Jatun, R. \& Magnadi, R. H. (2015). Analisis Faktor-Faktor yang berrpengaruh terhadap Keputusan Nasabah untuk Mengambil Pembiayaan pada Koperasi Jasa Layanan Syariah Pekalongan. Diponegoro Journal of Management, 4(2), 1-10.

94 | IQTISHODUNA Vol. 17 (1), 2021

http://ejournal.uin-malang.ac.id/index.php/ekonomi 
Mulyo, J. H. (2007). Revitalisasi ekonomi kerakyatan melalui pemberdayaan gerakan koperasi. http://io.ppi-jepang.org/article

Kholmi, M. (2002). Koperasi Berbasis Syraiah Islam sebagai Laternatif Pemberdayaan Ekonomi Rakyat. Jurnal Ilmiah Bestari, No 34 - Thn. XV.

Krisnamurti, B. (2007). Membangun koperasi berbasis anggota dalam rangka pengembangan ekonomi rakyat. www.ekonomirakyat.org/edisi4/artikel

Marlina, R. \& Pratami, Y. Y. (2017). KOperasi Syariah sebagai Solusi Penerapan Akad Syirkah yang Sah. Amwaluna: Jurnal Ekonomi dan Keuangan Syariah, 1(2), 263-275.

Munkner H. H. (2012). Co-Operation as a Remedy in Times of Crisis Agricultural Co-Operatives in the World Their Roles for Rural Development and Poverty Reduction. Political Science. Euricse Working Paper Series. DOI:10.2139/SSRN.2145317

Mursal \& Suhadi. (2015). Implementasi Prinsip Islam dalam Aktivitas Ekonomi: Alternatif Mewujudkan Keseimbangan Hidup. Jurnal Penelitian, 9(1), 67-92.

Mustaqim, M. (2016). Prinsip Syariah dalam Manajemen Sumber Daya Manusia. Jurnal Penelitian, 10(2), 399-422.

Miles dan Huberman. (1992). Analisis Data Kualitatif. Jakarta: Universitas Indonesia Press.

Qardhawi, Y. (2001). Peran Nilai dan Moral dalam Perekonomian Islam, Penerjemah K.H. Didin Hafidhuddin. Jakarta: Robbani Press.

Rafidah. (2014). Kualitas Pelayanan Islami pada Perbankan Syariah. Nalar Fiqh, 10(2).

Rivai, A. dan Darsono, P. (2015). Manajemen Strategis. Jakarta: Mitra Wacana Media.

Setyorini, W \& Kusumantoro. (2016). Peran Sumber Daya Manusia Koperasi dalam Aspek Penilaian Manajemen Penilaian Kesehatan Koperasi. Economic Education Analysis Journal. EEAJ 5 (1), 301-316.

Subadriyah., Rohman, F. (2015). Kompetensi Sumber Daya Manusia dan Pengaruhnya terhadap Kinerja Karyawan Bagian Akutansi Koperasi Simpan Pinjam di Kabupaten Jepara. JDEB, 12(2), 190-202.

Sukidjo. (2008). Membangun Citra Koperasi Indonesia. Jurnal Ekonomi dan Pendidikan, 5(2), 201-202. 
Witri Retno Handayani, Umrotul Khasanah

Triandini, H. (2013). Pengaruh Layanan Jemput Bola Produk Funding terhadap DPK dan Jumlah Nasabah: Studi pada BPRS Artha Karimah Irsyadi. Jurnal Etikonomi, 12(2), 131-148.

Triyuwono. (2002). Tradisi Islam dan Jawa untuk Pengembangan Koperasi. Makalah Seminar dan Lokakarya. PPI. Unibraw. Agustus. Malang 